Liturgia Sacra 24 (2018), nr 1, s. 273-285

DOI: $10.25167 / \mathrm{LitS} / 24(2018) 1 / 273-285$

Czestaw Grajewski

UKSW

\title{
Francuska polifonia liturgiczna XVII wieku w opracowaniu Miłosza Aleksandrowicza ${ }^{1}$
}

Badania naukowe nad muzyką liturgiczną w Polsce w ostatnim czasie zostały zintensyfikowane, czego dość dobrym wskaźnikiem są awanse naukowe ich autorów. Ten fakt dobitnie ukazuje, że eksploracja tego obszaru, po pierwsze, wciąż jest możliwa i przynosi bardzo dobre efekty, poszerza bowiem - niekiedy w stopniu istotnym - aktualny stan wiedzy, po drugie - jest inspiracją do podejmowania takowych wysiłków przez kolejne generacje naukowców.

Miłosz Aleksandrowicz zdecydował, że jego terenem badawczym stanie się teoria muzyki rozwijana zwłaszcza we Francji w okresie przełomu epok dawnej i nowożytnej. Terenem - dodajmy - endemicznym w polskiej muzykologii. W recenzowanej rozprawie jej autor podjął nierozpoznaną w polskim piśmiennictwie muzykologicznym problematykę francuskiej teorii muzycznej w zakresie odnoszącym się do muzyki liturgicznej. Stara się odpowiedzieć na pytanie o teoretyczny fundament sakralnej sztuki muzycznej w XVII-wiecznej Francji; w jakim stopniu owe teoretyczne podstawy są właściwe dla muzyki liturgicznej i czy noszą znamiona specificum wobec europejskiej, osobliwie zaś włoskiej myśli teoretycznej tamtego czasu. Należy zatem z radością powitać pierwsze, w dodatku tak obszerne, studium muzyczno-historyczne francuskiej praktyki muzycznej w kraju Ludwika XIII i Ludwika XIV.

Uważna lektura tego bardzo obszernego opracowania prowadzi do wniosku, że M. Aleksandrowicz na podstawie traktatów odtworzył (a nawet więcej: zrekonstruował) teoretyczne fundamenty francuskiej muzyki liturgicznej XVII i XVIII w. Może zabrzmi to górnolotnie, ale wykonał tę żmudną pracę za Francuzów i dla

${ }^{1}$ M. AleKSANDROwICZ, Teoretyczne podstawy francuskiej polifonii liturgicznej XVII wieku, Lublin 2017, Wydawnictwo Archidiecezji Lubelskiej „Gaudium”, ss. 675, ISBN 978-83-7548-287-4. 
Francuzów, poszerzając dotychczasowe rozumienie polsko-francuskich dążeń: „Za wiedzę waszą i naszą!” Tym większa więc zasługa autora, który wprowadzając do szerokiego obiegu naukowego bardzo wartościowe opracowanie problematyki francuskiej teorii muzycznej na podstawie kilkudziesięciu traktatów w większości francuskojęzycznych XVII w., do stanu wiedzy na ten temat wnosi rzeczywiście nową jakość i wymierny wkład. Słusznie zauważył na początku pracy, iż napisanie pełnej monografii muzyki liturgicznej tamtego czasu według opinii niektórych badaczy jest wręcz niemożliwe². Zatem - chwała autorowi!

Konstrukcja pracy ujawnia ogólny zamysł autora: ukazać problem od ogółu do szczegółu. Plan taki, metodologicznie jak najbardziej poprawny, ma na celu wprowadzenie czytelnika w problematykę ogólną, zanim zaznajomiony zostanie ze szczegółowymi i trudniejszymi zagadnieniami. Treść rozprawy liczącej 675 stron została rozdzielona między cztery komplementarne rozdziały sklamrowane Wprowadzeniem oraz Zakończeniem. Do tego doliczyć należy thumaczenie abstraktu na język angielski oraz spis wykorzystanej bibliografii. Praca nie zawiera aneksów, indeksów i innych elementów właściwych opracowaniom naukowym. Nie jest to powód do nadmiernego krytycyzmu, aczkolwiek przy tak obszernej pracy doskwiera brak choćby indeksu nazwisk.

Wprowadzenie obejmuje 10 stron (7-16) i jest klarownym zdefiniowaniem celu i przedmiotu badań oraz wyłożeniem zastosowanej metodologii badawczej. Kolejne rozdziały zawierają się w następującym zakresie stron: pierwszy 17-115 (99), drugi 117-376 (258), trzeci 377-540 (164) i ostatni 541-644 (102). Rozdział I stanowi tło historyczne, w rozdziale II nakreślone zostały w ogólności zagadnienia teorii aktualnej do zakresu tematycznego pracy, III rozdział, najściślej przylegający do tematu, ukazuje implementację teoretycznych założeń do praktyki kompozytorskiej i wreszcie w IV rozdziale autor, łącząc wątki z rozdziału I, zatacza koło hermeneutyczne (jak sam zdradził we Wprowadzeniu) $)^{3}$, próbując udzielić odpowiedzi na pytanie: „I co z tego wynikło?”. Zaletą takiej konstrukcji jest powiązanie treści rozdziałów w jedną, zwartą narracyjnie całość.

Walor dokumentacyjny rozprawy podnoszą fotogramy i przykłady muzyczne (często z dodaną transkrypcją na współczesny zapis), które zdecydowanie ułatwiają percepcję opisywanych, co w połączeniu z klarownością wywodu sprawia, że lektura mimo rozwlekłości narracji nawet niewtajemniczonemu czytelnikowi nie powinna sprawić trudności. Zakończenie jest zwięzłym podsumowaniem wniosków uzyskanych w toku badań i mieści się na pięciu stronach (645-649).

\footnotetext{
${ }^{2}$ M. AleKsandrowicz, Teoretyczne podstawy francuskiej polifonii liturgicznej XVII wieku, s. 7.

${ }^{3}$ Tamże, s. 12.
} 
Strona merytoryczna rozprawy nie budzi poważniejszych zastrzeżeń. Autor już we wcześniejszych publikacjach dał się poznać jako autorytet w kwestii teorii muzyki, szczególnie wczesnego okresu ery nowożytnej. Budzi szacunek oraz podziw metodyczność i - co za nią idzie - klarowność wywodu, momentami nawet rudymentarna. Nie sposób choćby w kilku zdaniach odnieść się do nadmiarowości informacji - cechy szczególnej tego skądinąd znakomitego opracowania. Owa redundancja sprawia wrażenie, jakby M. Aleksandrowicz postanowił w jednym tomie zawrzeć wszystko, co wie na temat francuskiej teorii muzyki XVII w. W rezultacie powstał kolejny traktat teoretyczny w rodzaju Compendium musicae, który równie dobrze mógłby nosić tytuł Francuski wkład w rozwój europejskiej teorii muzycznej, bo faktycznie praca zawiera mnóstwo znanych skądinąd informacji. Ale, żeby nie powstała wątpliwość, recenzent nie kwestionuje trafności tytułu rozprawy, sugeruje jedynie, że owe podstawy teoretyczne obejmują szerszy zakres niż tylko wymienioną polifonię religijną w XVII-wiecznej Francji. Wypełniając niewdzięczną rolę recenzenta, należy jednak podnieść pewne kwestie i wykazać zauważone istotniejsze mankamenty i pomyłki:

1. Za błędne uznać należy sformułowanie: „Fragmentami odmawianymi naprzemiennie (alternatim)"4. Technika alternatim nie dotyczyła recytacji modlitw czy psalmów, lecz naprzemiennej gry organowej i śpiewu (np. wierszy psalmowych), o czym w wielu innych miejscach autor wyraża się poprawnie ${ }^{5}$. Ponieważ na s. 58 ponownie czytamy o naprzemiennym sposobie śpiewu kantora i scholi, utożsamionego z pojęciem alternatim, należy tę nieścisłość skorygować. Nie chodzi nawet o sam termin, lecz o rozumienie śpiewu naprzemiennego. Otóż, kiedy chorał wykonywany jest na zmianę: kantor - schola, mówi się o śpiewie responsorialnym, natomiast kiedy kolejne wiersze psalmu wykonują naprzemiennie dwa zespoły śpiewacze (np. prawy i lewy chór), mówi się o wykonaniu antyfonalnym. Autor napisał był w tym miejscu, że „Ciąg dalszy psalmu był wykonywany naprzemiennie (alternatim) przez wyznaczonego śpiewaka i scholę”. Recenzent nie zna źródła pochodzenia tej informacji, ale w tradycji Kościoła od dawna praktykowany jest sposób wykonania psalmów przez dwa chóry (czyli antyfonalnie), a nie solistę i chór (responsorialnie). Autor w innym miejscu potwierdził ${ }^{6}$, że zna doskonale te pojęcia, czemu więc od czasu do czasu pojawia się takie nieporozumienie?

\footnotetext{
${ }^{4}$ Tamże, s. 53.

5 Tamże, s. 59, 77, 81, 85.

${ }^{6}$ Tamże, s. 94.
} 
2. M. Aleksandrowicz, cytując dzieło C. de La Croix, opisuje wykonanie responsorialne, starannie przy tym unikając tego fachowego określenia. Popełnia jednak przy tym błąd, tłumacząc, że werset ,wykonywany był zbiorowo" . O ile nie jest to fałszywa interpretacja tekstu francuskiego autora, należy zwrócić uwagę, że od wieków wykonanie wersetów responsorialnych należało do kantora, nie zaś do scholi. Temu przecież służyły księgi typu cantatoria i in. przeznaczone właśnie dla solistów ${ }^{8}$.

3. Ciąg dalszy problematyki wykonawstwa psalmodii. Wydaje się, że M. Aleksandrowicz ma kłopot $\mathrm{z}$ ustaleniem związku między psalmem i antyfoną, kilkakrotnie pisząc, że antyfonie przyporządkowany jest psalm9. Otóż jest dokładnie przeciwnie. To psalmy są podstawą liturgii brewiarzowej, zaś antyfony są zmienne, dostosowane do obchodu. Według reguły św. Benedykta psalmy mają swoje miejsce w oficjum każdego dnia tygodnia i to w taki sposób, by wszystkie 150 zostały wykonane w ciągu kolejnych siedmiu dni, po czym w kolejnym tygodniu cykl się powtarza ${ }^{10}$. Konkludując: to nie psalmy są przyporządkowane antyfonom, lecz antyfony skorelowane są z psalmami.

4. Niepotrzebnie chyba wyodrębnione zostały elementy składowe formy responsorialnej (responsa - werset - responsa) ${ }^{11}$. Jeśli autor już musiał (?) zaznaczyć układ Matutinum i jego kolejnych nokturnów, wystarczyłoby napisać zwyczajnie: responsorium 1, responsorium 2 itd. Wydzielenie bowiem poszczególnych składników (responsorium 1 - werset 1 - responsorium 1) nie dość, że stwarza wrażenie odrębności śpiewów, to jeszcze pogłębia zagmatwanie semantyczne. Responsorium to wszak cała forma muzyczna, na którą składa się responsa (lub: respons) oraz werset ${ }^{12}$.

5. Teraz kwestia instrumentologiczna. Autor wylicza: tubae, tibiae aut cornea, thumacząc te nazwy w kolejności odpowiednio: flety, trąbki i kornety ${ }^{13}$. Wydaje się, że poprawnie powinien napisać w następującej kolejności:

${ }^{7}$ M. Aleksandrowicz, Teoretyczne podstawy francuskiej polifonii liturgicznej XVII wieku, s. 61.

${ }^{8}$ E. Palazzo, A History of Liturgical Books from the Beginning to the Thirteenth Century, Collegeville 1993, s. 19. 60,61 .

9 M. Aleksandrowicz, Teoretyczne podstawy francuskiej polifonii liturgicznej XVII wieku, s. 58,

${ }^{10}$ Regula sancti Benedicti, 18, 22.

${ }^{11}$ M. Aleksandrowicz, Teoretyczne podstawy francuskiej polifonii liturgicznej XVII wieku, s. 62.

12 P. WiŚNIEWSKI, Śpiewy późnośredniowieczne w antyfonarzach płockich z XV/XVI wieku. Na podstawie responsoriów Matutinum, Lublin 2010, s. 172-173.

${ }^{13}$ M. AlEKSANDrowicz, Teoretyczne podstawy francuskiej polifonii liturgicznej XVII wieku, s. 75. 
trąbki, flety i rogi, choć i w tej konfiguracji zachodzą wątpliwości, czy tibię (instrument dęty stroikowy) można uznać za flet; raczej nie.

6. Kantyk Benedictus nie występuje w Jutrzni ${ }^{14}$, lecz na zakończenie Laudesów. W ogóle w Jutrzni żaden kantyk nie występuje, o czym M. Aleksandrowicz pośrednio zaświadcza ${ }^{15}$.

7. Trudno uchwytne błędy wdarły się do transkrypcji zapisu kwadratowego. Recenzent znalazł takowych kilka. Ostatnie współbrzmienie Alleluja powinno być prymą ${ }^{16}$ (tak wynika z oryginału). W transkrypcji oddano je jako sekundę (to zwyczajna pomyłka). W innym miejscu ${ }^{17}$, w zapisie sekwencji usterek jest natomiast więcej: w słowie doloros $\underline{\boldsymbol{a}}$ zachodzi undecyma między tenorem i basem. Jest tak w oryginale, to prawda, ale czy autor nie zwrócił na to uwagi?; lacrimosa - tu błąd M. Aleksandrowicza („FA” w basie jest błędne); pendebat - być może błąd w oryginale, ponieważ melodia w tym miejscu schodzi o sekundę w dół.

8. Z powyższych pomyłek zaistniałych we francuskich drukach autor wyciąga wniosek $^{18}$, że owe błędy drukarskie były efektem improwizacyjnej natury muzyki kościelnej we Francji XVII w. Rozumiemy i akceptujemy szczególne nabożeństwo M. Aleksandrowicza do kultury francuskiej, ale takie stanowisko wygląda na rozpaczliwą obronę kwestii, której obronić się nie da. Jeśli nawet $\mathrm{w}$ trakcie improwizacji organista się mylił (co nie powinno być powodem nadmiernej ekscytacji), to przecież mamy do czynienia $\mathrm{z}$ drukiem, a nie ze studyjnym nagraniem tejże improwizacji. Improwizacja improwizacją, ale kiedy na papier przelewa się własne pomysły muzyczne, to ma się możliwość dokładnej pracy i korekty zapisu na bieżąco. Reasumując: nie sądzę, by improwizacja była przekonującym wytłumaczeniem takich niedokładności drukarskich. Sam M. Aleksandrowicz także nie ustrzegł się pomyłek, pisząc przykłady muzyczne (vide punkt 7 niniejszej recenzji).

9. Na tle powyższych uwag drobiazgami wydają się potknięcia, jakimi są np. niepełne bądź niejednoznaczne podpisy pod przykładami: 106 - gdyż oprócz formuł II tonu na fotogramie uwidoczniono także ton $\mathrm{V}^{19}$; 191 -

\footnotetext{
${ }^{14}$ Tamże, s. 561.

15 Tamże, s. 62.

${ }^{16}$ Tamże, s. 563.

17 Tamże, s. 587.

18 Tamże, s. 598.

19 Tamże, s. 273.
} 
podpis sugeruje jedynie poprawne użycie kwarty, tymczasem wyraźnie widoczne jest umieszczenie przykładu również niepoprawnego użycia tego interwału ${ }^{20}$.

Wyliczone mankamenty nie rzutują w istotnym stopniu na ogólnie pozytywny obraz swej pracy. Ot, zwyczajnie w wielu przypadkach czytelnik tylko się skrzywi, ale bez większego trudu domyśli się, jakie treści autor chciał przekazać, a co naprawdę na kartach książki utrwalił.

Redakcja materiału w znakomitej większości została przeprowadzona rzeczywiście solidnie. Trzeba jednak wskazać na wyraźną uciążliwość, jaką są bardzo długie akapity ${ }^{21}$. Taki brak edytorskiego oddechu jest poważnym utrudnieniem podczas lektury. Wydaje się, że jest to pochodna większego problemu: wspomnianej już redundancji tekstu i nieuzasadnionej rozwlekłości narracji. Jeśli recenzent miałby postawić najważniejsze zarzuty autorowi ocenianej pracy, postawiłby trzy: dłużyzny, dłużyzny i jeszcze raz dłużyzny. Merytorycznie natomiast materiał jest bardzo dobrze przygotowany, poznawczo interesujący i naprawdę ważny.

Prawdopodobnie ktokolwiek inny, mający tę samą wiedzę do przekazania, zrobiłby to - powiedzmy - na 400, może 450 stronach, a nie blisko 700 ! Powstaje pytanie, co sam autor myśli o swoim „wyczynie”, czy obszerność opracowania nie stanowi dlań jakiegoś fetyszu, ponieważ czterystustronicowy traktat zaliczył do dzieł obszernych ${ }^{22}$. A żeby nie powstała żadna w tej sprawie wątpliwość u czytającego, zdradził się jeszcze, że hołduje popularnemu niegdyś sloganowi reklamowemu „Duży może więcej” w następujących sformułowaniach: „To krótkie, bo liczące zaledwie 61 stron dzieło ${ }^{23}$; I chociaż tego typu tekstów nie sposób uznać za «pełnowartościowe» traktaty (chociażby ze względu na niewielką liczbę stron), to jednak ich treść jest niezwykle cennym źródłem wiedzy"24. Tu chyba należy szukać wyjaśnienia fenomenu obszerności materiału. „Pełnowartościowy” dla M. Aleksandrowicza najprawdopodobniej znaczy „obszerny”. Autor popada jednak w sprzeczność: $Z$ jednej strony traktuje szczuplejsze źródło jako niepełnowartościowe, z drugiej, to samo źródło uznaje za poznawczo niezwykle cenne. I nie jest to przypadkowy lapsus, ponieważ nieco dalej podtrzymuje swoją opinię: „Pomimo tego, że tej bardzo krótkiej, liczącej zaledwie 22 strony, publikacji nie sposób

${ }^{20}$ M. Aleksandrowicz, Teoretyczne podstawy francuskiej polifonii liturgicznej XVII wieku, s. 430.

${ }^{21}$ Wybrane przykłady stron: 51, 52, 180, 181, 211, 212, 215, 432, 433, 590, 591.

${ }^{22}$ M. Aleksandrowicz, Teoretyczne podstawy francuskiej polifonii liturgicznej XVII wieku, s. $125,268$.

${ }^{23}$ Tamże, s. 129.

${ }^{24}$ Tamże, s. 122. 
uznać za traktat w pełnym tego słowa znaczeniu to jednak zawarte tam treści są bez wątpienia niezwykle istotne (...)"25. Co w takim razie autor skłonny byłby uznać za pełnowartościowy traktat?

Niech czytelnik sam odpowie na pytania: Czy dla zrozumienia teoretycznych podstaw kompozycji kościelnych trzeba znać szczegółowo dzieje kształtowania się śpiewu liturgicznego $\mathrm{w}$ dobie renesansu karolińskiego? ${ }^{26}$ Czy dla zrozumienia podstaw teoretycznych muzyki rozbrzmiewającej w XVII-wiecznej Francji należy rozwodzić się nad starogreckimi skalami? Zapytać dalej można wprost: Czy dla istoty przedstawionej pracy czytelnik musi przebrnąc przez opisy porządku liturgii włącznie ze wskazaniem momentów rozłożenia rąk przez celebransa, skłonienia głowy, założenia biretu, przyklęknięcia? Co ma do rzeczy dekoracja kościoła, liczba świec ${ }^{27}$ ? Z kolei, czy opis metody solmizacyjnej Gwidona z Arezzo ${ }^{28}$, która rzeczywiście była podstawą wykształcenia średniowiecznego muzyka, ma bezpośredni związek z tematem? A nawet gdyby, czy problem nie jest znany z innych publikacji, w tym polskojęzycznych? W dużej mierze ma się więc do czynienia ze skryptem do historii Kościoła francuskiego, historii liturgii, rozwoju systemu solmizacyjnego, co samo w sobie nie byłoby może naganne, gdyby nie było przedstawione w tak rozwlekły i szczegółowy sposób.

I niejednokrotnie na kartach dysertacji autor potwierdza obserwację o tym, że w swoich dywagacjach od zasadniczego wątku odszedł zbyt daleko, bo o czym innym mogą świadczyć inicja akapitów w rodzaju: „Ale wróćmy do Francji XVII wieku; Wracając do tematu...? A tu jeszcze wyraźniej: Spoglądając całościowo na treść tych traktatów, które nie odnoszą się bezpośredni(o) do francuskiej praktyki liturgiczno-muzycznej XVII wieku"29. W obszarze dziedzin innych niż muzyka autor sięga nawet do Galileusza z teleskopem i plam na słońcu ${ }^{30}$. Dalej: opisując sposób strojenia organów, prowadzi czytelnika przez mordercze szczegóły akustyki, by w końcu dojść do interesującej konkluzji, że systemy temperacji w XVII-wiecznej Francji (czyli czasie, o jakim traktuje dysertacja) były zachowawcze ${ }^{31}$. Znów: Czy nie dało się tego ująć w zwięzły sposób? Wydaje się, że takie dłużyzny istnieją jedynie na potwierdzenie erudycji autora - dodajmy wyraźnie: Znakomitej i niekwestionowanej!

\footnotetext{
25 Tamże, s. 130.

26 Tamże, s. 33-35.

27 Tamże, s. 47-53, 57-62.

28 Tamże, od s. 186.

29 Tamże, s. 145.

30 Tamże, s. 146-147.

31 Tamże, s. 216-225.
} 
Jakby mało było tego, autor po wielekroć wraca do zagadnienia raz już przedstawionego. Istnieją pojęcia logorea, słowotok, niemniej odnoszą się one do języka mówionego. Autor, niestety, nie ustrzegł się tego niebezpieczeństwa, nie dostrzegając różnicy między językiem mówionym i językiem pisanym. Trudno wręcz zliczyć, ile razy została powielona informacja o tym, że chorał gregoriański stanowi muzyczny nucleus francuskiej liturgii XVII w. Mamy tę świadomość już od co najmniej s. 57, więc całkowicie zbędne jest nieustanne epatowanie czytelnika tym pewnikiem. Wystarczy zajrzeć na s. 541, by znaleźć tego potwierdzenie, na s. 546, w dwóch miejscach odległych zaledwie o kilkanaście wierszy, można przeczytać o tym ponownie, a gdyby komuś to było jeszcze za mało, również na sąsiedniej 547. Niewiele dalej, na s. 560, kolejny raz to samo. Z pewnością ta informacja pojawiała się w wielu innych miejscach książki.

A że można istotne nawet treści oddać w sposób zwięzły, M. Aleksandrowicz udowadnia w swej pracy niejednokrotnie. Przykładowo: udało mu się syntetycznie ująć treść istotną z punktu widzenia tematyki pracy ${ }^{32}$. W innych miejscach zwięźle, a przy tym umiejętnie autor łączy wątki muzyczne z pozamuzycznymi - homiletyką i retoryką ${ }^{33}$, malarstwem ${ }^{34}$, nauką o języku ${ }^{35}$. Dalej: omawiając zmiany, jakie zaszły w postrzeganiu wielogłosowości przez francuskich kompozytorów w XVII w., krótko, a przy tym jasno i bez wątpliwości to opisuje ${ }^{36}$. W tym zakresie należy wyrazić uznanie dla klarowności wywodu, z jakim ma się do czynienia w całym ogólnie IV rozdziale. A więc można. Wydaje się przy tym, że ostatni rozdział książki jest tym, o którym można z satysfakcją powiedzieć, że ,jest do czytania”. Właśnie o taki rodzaj wypowiedzi należałoby do autora, znakomitego erudyty, zaapelować.

Język rozprawy jest komunikatywny, powodujący, że lektura nie nastręcza trudności w przyswojeniu treści, od strony naukowej bez większych zastrzeżeń, wskazujący na dobre opanowanie metody i terminologii, co trzeba podkreślić i docenić. Tekst nie jest w przesadny sposób naładowany specjalistyczną nomenklaturą, co sprawia, że dysertacja jest dostępna poznawczo każdemu zainteresowanemu tą tematyką. Autor umiejętnie, a przy tym bez egzaltacji posługuje się łaciną, wtrącając zwroty z tego języka, co jest naturalne, a nawet oczekiwane w pracy z zakresu muzyki liturgicznej.

${ }^{32}$ M. Aleksandrowicz, Teoretyczne podstawy francuskiej polifonii liturgicznej XVII wieku, s. 53, pierwszy akapit.

33 Tamże, s. 104.

34 Tamże, s. 105-106.

35 Tamże, s. 110.

${ }^{36}$ Tamże, s. 472-473. 
Pozostając jeszcze w obszarze języka, jakim napisana jest rozprawa, trzeba wytknąc autorowi obsesyjne wręcz podawanie w nawiasach thumaczenia na język polski charakterystycznych francuskich słów. Zgoda, należy to uczynić, ale gdy pojawiają się one po raz pierwszy, ewentualnie drugi - w końcu tytułowy temat zwiastuje problematykę zawartą w teoretycznych pismach francuskich. Jednak ileż razy można powtarzać: „temat (sujet)”? M. Aleksandrowicz z tego zwrotu uczynił chyba jakieś zaklęcie, wszak nie ma bodaj kilku kolejnych stron, na których przynajmniej raz nie pojawiłby się zwrot: „temat (sujet) "37, aż do irytacji. Na s. 473 w pięciu kolejnych wierszach fraza ta występuje aż trzykrotnie. Zaraz dalej jest jeszcze intensywniej: na s. 476 sujet w połączeniu z polskim ,temat” występuje aż sześciokrotnie i na kolejnej jeszcze cztery razy.

Bardziej skomplikowana jest sprawa z terminem modulation. Autor thumaczy go jako „modulacyjność”38. Hm, sztuką jest powiedzieć coś, by nie powiedzieć niczego. Słowo modulation od czasu napisania traktatu przez św. Augustyna ${ }^{39}$ zrobiło w piśmiennictwie „karierę” i wiele tęgich głów próbowało znaleźć właściwe jego thumaczenie. $Z$ tego powodu recenzent ze szczególnym zainteresowaniem śledził ów wątek na kartach rozprawy, ale autor dość długi czas kluczył, rozwodząc się bardziej nad tym, czym jest poprawna i niepoprawna modulacyjność, wyjaśnienie samego terminu odkładając aż do s. 175! Od tego dopiero miejsca podejmuje próbę dotarcia do „korzenia znaczeniowego”, zaznaczając, że jest to konieczne. I w napięciu czytelnik czeka na wyjaśnienie terminu modulation, tak jak rozumieli go teoretycy francuscy XVII w. a nawet później - w XVIII, XIX i XX w. Wydaje się, jakby M. Aleksandrowicz na jakiś czas zapomniał, o czym miał napisać pracę. A przecież, zamiast wykładać całą historię przemiany znaczenia tego terminu, mógł zwięźle napisać, że w XVII w. pod pojęciem modulation skrywały się dwa pojęcia: dawniejsze, oznaczające sposób istnienia melodii, oraz współczesne - jako płynne przejście do innej tonacji.

In plus natomiast trzeba zaliczyć M. Aleksandrowiczowi próbę wprowadzenia nowego terminu: „machikotyzm”" ${ }^{40}$. Trudno przesądzić, czy ten termin przyjmie się w języku nauki i w ogóle w języku polskim, ale wobec braku alternatywy należy odnieść się do tej propozycji z uznaniem, zwłaszcza że we wskazanym miejscu jasno i klarownie wytłumaczone jest, co ów neologizm miałby oznaczać. Nieco go-

37 Tamże, s. 472, 473, 476, 477.

38 Tamże, s. 111.

${ }^{39} \mathrm{Ph}$. Stoltzfus, Theology as Performance. Music, Aesthetics, and God in Modern Theology, New York - London 2006, s. 28-29.

${ }^{40}$ M. AleKsandrowicz, Teoretyczne podstawy francuskiej polifonii liturgicznej, s. 562. 
rzej poszło $z$ terminem perielesy ${ }^{41}$, ale przynajmniej autor podjął próbę zmierzenia się z przetłumaczeniem tego słowa, bo już trudno natknąć się na próby tłumaczenia określeń np. sacquebute (puzon - czy autor bał się tego słowa?) ${ }^{42}$, je ne sçai qoui ${ }^{43}$, broderie $^{44}$.

Aparat krytyczny jest tym wyznacznikiem, który najwyraźniej separuje literaturę naukową od pozostałych gatunków piśmiennictwa i na który trzeba zwracać baczną uwagę, ponieważ w nim najczęściej ukrywają się niedokładności. Także i opracowanie M. Aleksandrowicza nie jest w tym zakresie wyjątkiem.

Najpierw bibliografia. Na szczególne uznanie zasługuje obfitość wykorzystanej literatury, zwłaszcza obcojęzycznej. Aż ciśnie się na usta pytanie, dlaczego autor nie przedstawił tej dysertacji na którymś z wydziałów uniwersytetu np. w Paryżu?

Studiując bibliografię, czytelnik pewnie zadaje sobie pytania o zasadność uznania przedziału czasowego (stulecia) jako nadrzędnego kryterium podziału źródeł oraz o powód rezygnacji z tradycyjnego podziału bibliografii na źródła i opracowania, encyklopedie i słowniki, dzieląc np. źródła na muzyczne i liturgiczne według wieku powstania. Z tym bowiem wiążą się określone trudności. Oto pierwsze z brzegu: Czy antyfonarz (zawierający przecież bardzo dużo zapisu nutowego) to źródło muzyczne czy liturgiczne? Autor umieścił je wśród liturgicznych, co jest oczywiście prawdą ${ }^{45}$, ale czy tym samym nie odmawia antyfonarzowi waloru „muzyczności”?

Pozostawiając odpowiedzi na powyższe wątpliwości autorowi, wypada przypatrzeć się bliżej spisowi literatury, w którym bez większego trudu można odkryć brak dostatecznej staranności. Wymienię niektóre usterki, których większość zdaje się sugerować skopiowanie $\mathrm{z}$ innych prac (nie jest to zarzut - po prostu różne wydawnictwa stosują różne wymagania w zakresie konstrukcji zapisu bibliograficznego). I tak:

Praca Rosario Villari, Człowiek baroku, Warszawa 2001, według zapisu wydaje się monografią jednego autora ${ }^{46}$. Tymczasem nie jest to prawda. Jest to nazwisko redaktora wieloautorskiej książki, w której tenże zamieścił jeden z artykułów. Zapis bibliograficzny akurat tej pozycji ma jeszcze jedną wadę, mianowicie pominięcie

\footnotetext{
${ }^{41}$ M. AleKsandrowicz, Teoretyczne podstawy francuskiej polifonii liturgicznej XVII wieku, s. 562.

42 Tamże, s. 78.

43 Tamże, s. 482.

44 Tamże, s. 580.

45 Tamże, s. 657.

46 Tamże, s. 671.
} 
nazwisk tłumaczy wydania polskiego (jego tłumaczkami są Bogumiła Bielańska, Monika Gurgul i Monika Woźniak).

Niedokładny zapis widnieje w poz. $460^{47}$. E. de Coussemaker jest redaktorem serii Scriptorum de musica medii aevi, a nie autorem, jak by wynikało z zapisu zastosowanego przez autora. W poz. 478 podobna informacja jest podana prawidłowo. Mankamentem jest nieuwzględnienie w bibliografii Processionale romanum ad usum fratrum minorum (Paris 1629), z którego autor zaczerpnął zapis sekwencji Stabat Mater ${ }^{48}$. Szkoda, że ta pozycja nie została ujęta, ponieważ ze względu na pomyłki drukarskie (o których wyżej) warto byłoby wiedzieć, w której oficynie została wydana.

Kolejne uwagi dotyczą rozbieżności w zapisie tych samych (!) pozycji. Oto Traicte des libertez... Paris 1608 w przypisach ${ }^{49}$ figuruje jako Anonim, zaś w bibliografii jako $[-]^{50}$. Niewiele to zmienia w sferze poznawczej, jednak komplikuje posługiwanie się aparatem krytycznym. Warto odnotować, że z tego powodu Nouvelle méthode pour apprende... ujęta została dwukrotnie: pierwszy raz jako [-], drugi raz jako Anonim. W dodatku oba zapisy tytułów różnią się szczegółowością ${ }^{51}$.

Niedokładności pewnie znalazłoby się więcej, nie o to chodzi jednak, by przeistaczać się w księgowego szukającego każdego grosza. Chodzi raczej o uwrażliwienie na dokładność, bez której nie powinno się kierować do druku opracowania naukowego, zwłaszcza gdy nie ma ono zapewnionej solidnej korekty. Dokładnie zredagowana praca jest nie tylko bardziej estetyczna, ale i wzbudza większe zaufanie do rezultatów badań.

I na koniec uwaga krytyczna w kwestii technicznej. W książce pojawiła się dość trudno wytłumaczalna usterka polegająca na braku nadruku na karcie tytułowej roku wydania książki. Można sobie wyobrazić irytację badaczy w momencie konieczności zacytowania fragmentu bądź odwołania się do dysertacji M. Aleksandrowicza! Uwalniam jednak autora od odpowiedzialności za niedokładną pracę redakcji, natomiast opinię o jego spostrzegawczości zatrzymam sub pectore.

Czas na rekapitulację. Lektura opracowania Miłosza Aleksandrowicza potwierdza w pełni zasadność podjęcia wysiłku i napisania monografii na temat teoretycznych podstaw muzyki francuskiej w XVII w. i podjęcia żmudnej kwe-

47 Tamże, s. 670.

48 Tamże, s. 587.

49 Tamże, s. 40.

${ }^{50}$ Tamże, s. 657.

${ }^{51}$ Tamże, s. 655. 
rendy. Powstała obszerna, zarówno w warstwie merytorycznej, jak i objętości, solidnie udokumentowana źródłowo praca, która jest ważnym osiągnięciem polskiej muzykologii. Autor, mimo pewnych niedociągnięć, przedstawił napisaną przystępnym językiem przejrzystą dysertację na ważny dla historii kultury religijnej we Francji temat. Z uznaniem należy odnieść się do wysiłku autora, który skrupulatnie prześledził kilkadziesiąt traktatów teoretycznych oraz źródeł muzyki liturgicznej i w efekcie wyizolował zasady, na podstawie których formułuje cenne wnioski.

Recenzowana praca jest cenna od strony poznawczej. Czytelnik dostaje naprawdę solidną dawkę naukowych informacji, których dotąd zwłaszcza w polskim piśmiennictwie nie uwzględniano. Niektóre z tych informacji dotyczą spraw drobnych - np. wskazanie praktyki obowiązkowego wykonania wokalnego strofy Te ergo quaesumus w hymnie Te Deum, nie zaś instrumentalnie ${ }^{52}$; złej praktyki wykrzykiwania wersetów psalmowych podczas gry organowej ${ }^{53}$; praktyki wykonywania wielogłosowego wykonywania fragmentów neumatycznych w częściach zmiennych mszy ${ }^{54}$. Niektóre dotykają jednak spraw fundamentalnych, np. strojenia organów (par. 4.3 rozdz. II); charakterystyki tzw. śpiewu z księgi (par. 2 rozdz. IV), stanowiącej novum w rodzimej literaturze; próby ukazania, w jaki sposób założenia teoretyczne budownictwa organowego odzwierciedlane były w praktyce muzycznej (od s. 61). Łącznie jest to pokaźny zasób wiedzy, za zebranie i udostępnienie którego należą się M. Aleksandrowiczowi słowa najwyższego uznania.

Bardzo ważne są również dociekania, które pozwoliły autorowi na powiązanie stanu muzyki liturgicznej z samą liturgią mimo skąpych danych ze źródeł historycznych. Interesujące są próby odpowiedzi na pytanie, czy rytmika francuskiej muzyki organowej XVII w. była istotnym zagadnieniem dla ówczesnych teoretyków. M. Aleksandrowicz wykazał, że nie ${ }^{55}$. To dość zaskakująca konstatacja, ale rozumiem i przyjmuję tok dowodowy przedstawiony przez autora.

Z nieukrywaną satysfakcją śledzić można wysiłek autora w celu ustalenia przyczyn słabego oddziaływania muzyki na słuchaczy (w kontekście zagadnienia afektywności), jakie obserwowali w swoim czasie Jumilhac oraz Maillart ${ }^{56}$. Powiązanie oczywistego, negatywnego efektu słabej gry instrumentalisty z teorią afektów, nawet jeśli nie pochodzi bezpośrednio od autora opracowania, warte jest zastanowie-

\footnotetext{
${ }^{52}$ M. AleKsandrowicz, Teoretyczne podstawy francuskiej polifonii liturgicznej XVII wieku, s. 61.

${ }^{53}$ Tamże, s. 560.

54 Tamże, s. 564.

55 Tamże, s. 302.

56 Tamże, s. 102-104.
} 
nia. W tymże samym miejscu M. Aleksandrowicz bardzo ładnie ukazuje krytykę źródła - podstawę metodologii każdego historyka.

Również z ogromnym zainteresowaniem podąża się za tokiem myślenia autora, gdy w paragrafie 6.3. bardzo ładnie naświetlił przyporządkowanie śpiewów kościelnych do konkretnej skali modalnej. Ten problem, jak widać, nie został rozwiązany u schyłku średniowiecza, chociaż rezygnacja z tonariuszy wydawałoby się tę kwestię ostatecznie zamknęła ${ }^{57}$.

Widoczna jest w rozprawie metoda hermeneutyczno-muzyczna, której sedno można sprowadzić do zasady potraktowania problemu badawczego w taki sposób, by w umyśle czytelnika dokonał się proces intelektualnej rekonstrukcji świata historycznego. Wszystko to przemawia na korzyść Miłosza Aleksandrowicza, ale dla dobra sprawy - powtórzmy na koniec raz jeszcze - lepiej byłoby, gdyby autor podczas pisania dysertacji kierował się jedną z podstawowych zasad ekonomicznej minimalizacji środków przy jednoczesnej maksymalizacji efektów, która w ujęciu Leibniza brzmi: „W rzeczach zawsze obowiązuje zasada, aby największy skutek osiągany był minimalnym nakładem" 58 .

Praca Miłosza Aleksandrowicza Teoretyczne podstawy francuskiej polifonii liturgicznej XVII wieku jest pierwszą publikacją w języku polskim, w której autor tak szeroko podjął problematykę teoretycznych fundamentów francuskiej sakralnej muzyki wielogłosowej. Przedstawione wyniki drobiazgowych analiz stawiają to zagadnienie w nowym oświetleniu. Z pewnością będzie to pozycja, na którą będą musieli powołać się badacze muzyki nowożytnej, której źródła tkwią w chorale gregoriańskim.

${ }^{57}$ Por. J. Morawski, Nieznane przekazy dwu tonariusów z antyfonarzy śląskich XIII i XIV w., „Saeculum Christianum” 9 (2002), nr 2, s. 29.

${ }^{58}$ Por. T. GosPodareK, Aspekty złożoności i filozofii nauki w zarządzaniu, Wałbrzych 2012, s. 160. 